\title{
Cladocerans from gut content of fishes from Guaporé River Basin, MT, Brazil
}

Cladóceros do conteúdo estomacal de peixes da Bacia do Rio Guaporé, MT, Brasil

Lourdes Maria Abdu Elmoor-Loureiro and Carlos Eduardo Aguiar Soares

Laboratório de Zoologia, Universidade Católica de Brasília - UCB,

QS 7 lote 1, Bloco M sala 331, Taguatinga, DF, Brazil

e-mail: lourdes@ucb.br, c.sawabona@gmail.com

\begin{abstract}
Aim: the present study aimed to identify the cladoceran species taken from the gut content of fishes sampled from Vila Bela da Santíssima Trindade (Mato Grosso); Methods: the gut content of 14 individual fishes were analyzed; from each one, at least 100 individual cladocerans were identified; Results: A total of 25 cladoceran species were registered, providing the first species list for Guaporé River Basin, seven of them reported from Mato Grosso State for the first time; Conclusions: Besides the information on Cladoceran occurrence, the study point out the importance of this organisms in the aquatic food web of Guaporé Basin.
\end{abstract}

Keywords: fish gut content, Cladocera, zooplankton, Amazon Basin.

Resumo: Objetivo: o presente estudo buscou identificar os cladóceros observados no conteúdo estomacal de peixes coletados em Vila Bela da Santíssima Trindade (Mato Grosso); Métodos: os conteúdos estomacais de 14 peixes foram observados, sendo que para cada um foram identificados um mínimo de 100 exemplares de cladóceros; Resultados: Foram identificadas 25 espécies de cladóceros, fornecendo a primeira lista de espécies para a Bacia do Rio Guaporé, sete delas reportadas pela primeira vez para o estado do Mato Grosso; Conclusóes: Além de informaçôes sobre a ocorrência de cladóceros, o estudo salientou a importância desses organismos na cadeia alimentar aquática da bacia do Rio Guaporé.

Palavras-chave: conteúdo estomacal de peixes, Cladocera, zooplâncton, Bacia Amazônica.

\section{Introcution}

Cladocera and Copepoda are the biggest organisms in the zooplankton community, so they are usually selected as preferential food by planktivorous fish. However, cladocerans seem to be more consumed than copepods, as observed in a study on Hyphessobrycon bifasciatus Ellis, 1911, independently of the fish size class (Coutinho et al., 2000). The fish preference for cladocerans could be related to the prey mobility, as cladocerans move slower and more compassed than copepods, which swim faster and show rapid changes of direction (Carvalho, 1980).

Cladocerans (Branchiopoda) are present in variable proportions in the diet of fishes. Vela (1991) observed that cladocerans were the main component of the Melaniris sardina (Meek, 1907) and Astyanax fasciatus (Cuvier, 1819) diet in lake Xototlán (Nicaragua). Cladocerans were found in the gut content of several Brazilian fishes such as Brycon amazonicum (Spix and Agassiz, 1829) (Leite, 2004), Bryconomericus stramineus
Eigenmann 1908 (Crippa et al., 2009), Geophagus brasiliensis Quoy and Gaimard, 1824 (Dias et al., 2005), Hyphessobrycon bifasciatus (Coutinho et al., 2000), Hyphessobrycon eques (Steindachner, 1882) (Crippa et al., 2009), Metynnis maculatus (Kner, 1860) (Dias et al., 2005), Metynnis mola Eigenmann and Kennedy, 1903 (Resende et al., 1998), Moenkhausia dichroura (Kner, 1858) (Resende et al., 2000; Novakowski et al., 2008), Moenkhausia sanctaefilomenae (Steindachner, 1907) (Crippa et al., 2009), Odontotesthes bonariensis Cuvier and Valenciennes, 1835 (Cassemiro et al., 2003; Piedras and Pouey, 2005), Rivulus pictus Costa, 1989 (Shibatta and Bennemann, 2003), Simpsonichlhys boitonei Carvalho, 1959 (Shibatta and Rocha, 2001), and Triportheus paranensis (Günther, 1874) (Galina and Hahn, 2003).

The knowledge on the Cladocera fauna in the Brazilian Center-West region is poor, despite the importance of local hydrographic basins, and there 
are wide areas still unstudied (Elmoor-Loureiro, 2000). The use of gut contents can represent a viable alternative to direct sampling and can constitute relevant sources of information for the species occurrence.

This is the case of the present study, which aimed to identify the cladoceran species present in the gut content of fish collected near Vila Bela da Santíssima Trindade, Mato Grosso, in the upper Guaporé River.

\section{Material and Methods}

The Guaporé River basin, located at the Northwest part of the Mato Grosso State, is part of the Amazon basin, and is tributary of the Madeira River (Figure 1). Along the Guaporé River course, small lakes are observed, locally named as "baías", which are connected to the main flow when the river water level is high (Fachín-Terán and Vogt, 2004).

The cladoceran specimens analyzed in the present study were found in the gut content of the Characidae fishes Moenkhausia dichroura and Metynnis mola.
Fourteen individual fishes were collected in December/06 from Baia Soca-Soca (15 $1^{\circ}$ ' 22" S and $59^{\circ} 57^{\prime} 50^{\prime \prime} \mathrm{W}$ ) and Baia do Luiz (14.59' $16^{\prime \prime} \mathrm{S}$ and $59^{\circ} 58^{\prime} 09^{\prime \prime}$ W), both located near Vila Bela da Santíssima Trindade (Figure 1). The fishes were fixed with formalin $10 \%$ and their digestive tract was excised. The cladocerans were sorted from gut content under stereomicroscope and transferred to alcohol $70 \%$. For cladoceran identification, the specimens were analyzed in total or until a minimum of 100 specimens. The voucher specimens were deposited at the Zoology Laboratory of the Universidade Católica de Brasília.

\section{Results and Discussion}

In total, 25 cladoceran species were found in the gut content of fishes from Guaporé River (Table 1), providing the first species list for this basin. Of the species recorded, seven were not reported from Mato Grosso State in previous studies (Green, 1972; Neves et al., 2003).

The occurrence of Guernella raphaelis Richard, 1892, Moina reticulata (Daday, 1905), and Moinodaphnia macleayi (King, 1853) in the Guaporé

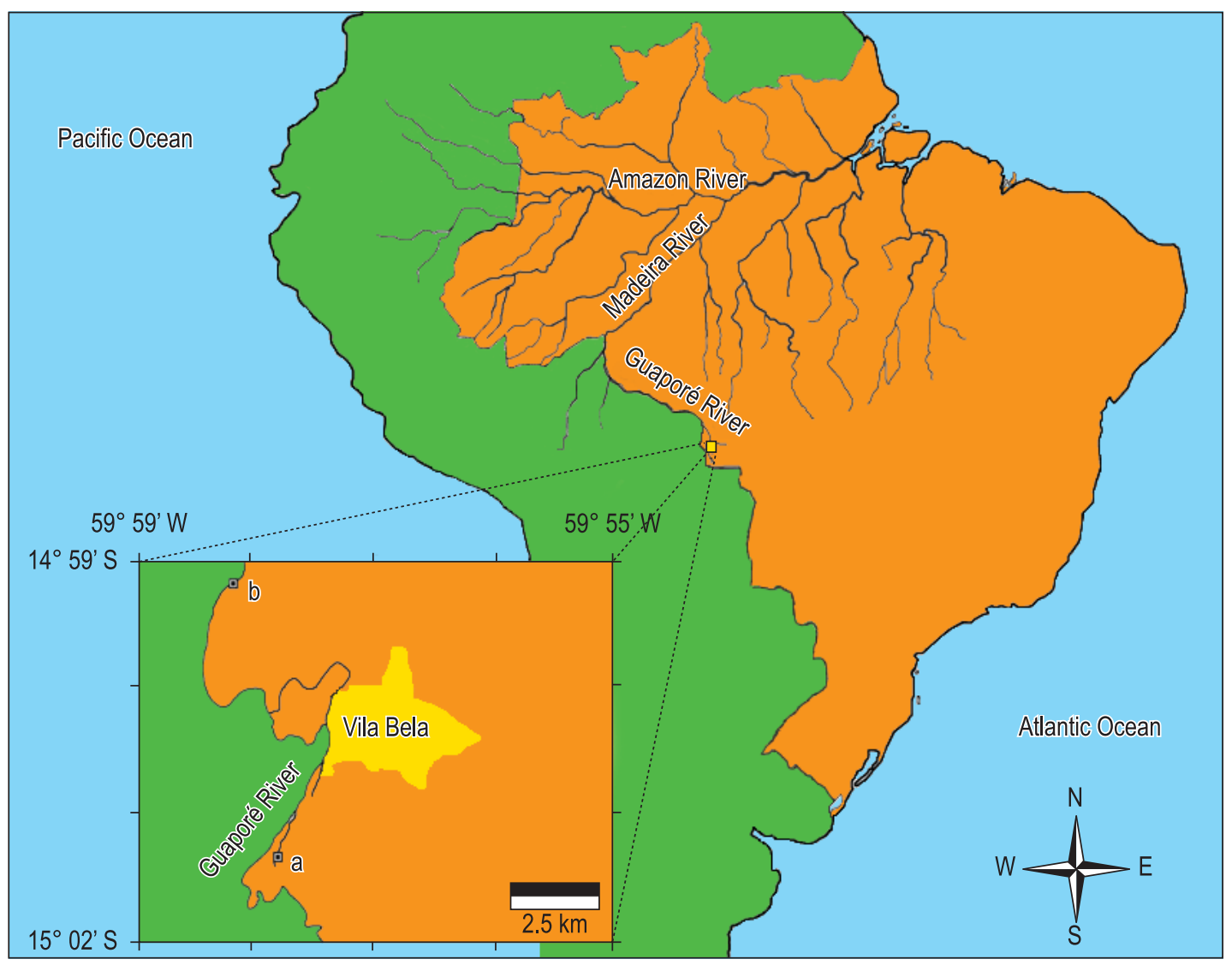

Figure 1. Schematic representation of the Amazon Basin, and location of the sampling sites, near Vila Bela da Santíssima Trindade, Mato Grosso State, Brazil (a: Baía Soca-Soca; b: Baía do Luiz). 
Table 1. List of species found in the gut content of Moenkhausia dichoura and Metynnis mola from Guaporé River basin.

\begin{tabular}{l} 
Species \\
\hline Sididae Baird, 1850 \\
Diaphanosoma birgei Korineck, 1981 \\
Diaphanosoma spinulosum Herbst, 1967 \\
Diaphanosoma brevireme Sars, 1901 \\
Pseudosida ramosa (Daday, 1904) \\
Sarsilatona behningi Korovchinsky, 1985 \\
Daphiniidae Straus, 1820 \\
Ceriodaphnia cornuta Sars 1886 \\
Moinidae Goulden, 1968 \\
Moina minuta (Hansen, 1899) \\
Moina reticulata (Daday, 1905) \\
Moinodaphnia macleayi (King, 1853) \\
Bosminidae Sars, 1865 \\
Bosminopsis deitersi Richard, 1895 \\
Macrothricidae Norman and Brady, 1867 \\
Guernella raphaelis Richard, 1892 \\
Macrothrix brandorffi Kotov and Hollwedel, 2004 \\
Macrothrix elegans Sars, 1901 \\
Macrothrix squamosa Sars, 1901 \\
Ilyocryptidae Smirnov, 1992 \\
Ilyocryptus spinifer Herrick, 1882 \\
Chydoridae Stebbing, 1902 \\
Alona ossiani Sinev, 1998 \\
Alonella dadayi (Birge, 1910) \\
Chydorus eurynotus Sars, 1901 \\
Chydorus pubescens Sars, 1901 \\
Euryalona orientalis (Daday, 1898) \\
Graptoleberis occidentalis Sars, 1901 \\
Karualona mülleri (Richard, 1897) \\
\hline
\end{tabular}

-Indicates the first records from Mato Grosso State.

basin is not surprising, because their presence in the Amazon basin was already kwown (Stingelin, 1904; Robertson, 1980; Elmoor-Loureiro, 2000).

Although not previously reported from Amazon basin, Leydigiopsis ornata Daday, 1905 occurs from the Pantanal (Hollwedel et al., 2003) to Venezuela (Rey and Vazquez, 1986). So, this record in Guaporé basin is located within the species known distribution range.

The Brazilian records of Kurzia polyspina Hudec, 2000, until now, include only the Distrito Federal (Elmoor-Loureiro, 2002) and Mato Grosso do Sul (Hollwedel et al., 2003). Robertson (1980) reported the occurrence of Kurzia latissima (Kurz, 1874) from Pará, but it is possible that it might belong to $K$. polyspina, as previously discussed
(Elmoor-Loureiro, 2002). So, the present record is the first confirmed from the Amazon basin.

Sarsilatona behningi Korovchinsky, 1985 and Macrothrix brandorff Kotov and Hollwedel, 2004 were originally described from Amazonian water bodies: S. behningi from Lago Castanho (Amazonas) and $M$. brandorffi from a lagoon near Rio Branco (Roraima). The present records are the first out of type localities and, therefore, they extend the distribution of these species $1000-2000 \mathrm{~km}$ to South.

The fish $M$. dichroura is known to be omnivorous (Wantzen et al., 2002), but sometimes can be planktivorous (Novakowski et al., 2008). Resende et al. (2000) observed that cladocerans were the predominant food item of $M$. dichroura in Miranda River floodplain (MS). The majority of the observed cladoceran species $(73 \%)$ collected from the gut contents of the fishes are typical members of the littoral community, which is the case of Moinodaphnia macleayi, Pseudosida ramosa, Sarsilatona behningi, and the species belonging to families Chydoridae, Macrothricidae, and Ilyocryptidae. This fact indicates that, at least partially, $M$. dichroura eats in the littoral zone.

On the other hand, Metynnis mola is mainly herbivorous, but can consume cladocerans when they are abundant (Resende et al., 1998; Wantzen et al., 2002). M. mola uses to eat among littoral vegetation, searching for filamentous algae, its main food resource, sometimes cutting aquatic macrophytes to obtain it (Machado, 2003). As many cladoceran species inhabit such environment, it is possible that they would be accidentally consumed.

Besides the information on Cladoceran occurrence, the study point out the importance of this organisms in the aquatic food web of Guaporé Basin.

\section{Acknowledgments}

Our sincere thanks to Dr. Eucilene Alves Santana Porto (Brazilian Ministry of Health), for providing the cladoceran samples. We also thank Universidade Católica de Brasilia and Conselho Nacional de Desenvolvimento Científico e Tecnológico (grant $555288 / 2006-4)$ for the financial support.

\section{Referências}

CARVALHO, FM., 1980. Alimentação do mapará (Hypophthalmus edentatus Spix, 1829) do lago do Castanho, Amazonas (Siluriformes, Hypophalmidae). Acta Amazonica, vol. 10, p. 545-555.

CASSEMIRO, FAS., HAHN, NS. and RANGEL, TFLVB., 2003. Diet and trophic ecomorphology 
of the silverside, Odontesthes bonariensis, of the Salto Caxias reservoir, Rio Iguaçu, Paraná, Brazil. Neotropical Ichthyology, vol. 1, no. 2, p. 127-131.

COUTINHO, AB., AGUIARO, T., BRANCO, CWC., ALBUQUERQUE, EF. and SOUZA FILHO, IF., 2000. Alimentação de Hyphessobrycon bifasciatus Ellis, 1991 (Osteichthyes, Characidae) na lagoa Cabiúnas Macaé, RJ. Acta Limnologica Brasiliensia, vol. 12, p. 45-54.

CRIPPA, VEL., HAHN, NS. and FUGI, R., 2009. Food resource used by small-sized fish in macrophyte patches in ponds of the upper Paraná river floodplain. Acta Scientiarum, Biological Sciences, vol. 31, no. 2, p. 119-125.

DIAS, ACMI., BRANCO, CWC. and LOPES, VG., 2005. Estudo da dieta natural de peixes no reservatório de Ribeiráo das Lajes, Rio de Janeiro, Brasil. Acta Scientiarum Biological Sciences, vol. 27, no. 4, p. 355-364.

ELMOOR-LOUREIRO, LMA., 2000. Brazilian cladoceran studies: where do we stand? Náuplius, vol. 8 , no. 1 , p. 117-131.

ELMOOR-LOUREIRO, LMA., 2002. Occurrence of Kurzia polyspina Hudec, 2000 (Crustacea, Anomopoda, Chydoridae) in Brazil. Revista Brasileira de Zoologia, vol. 19, no. 1, p. 305-307.

FACHÍN-TERÁN, A. and VOGT, RC., 2004. Estrutura populacional, tamanho e razão sexual Podocnemis unifilis (Testudines, Podocnemididae) no rio Guaporé (RO), norte do Brasil. Phyllomedusa, vol. 3, no. 1, p. 29-42.

GALINA, AB. and HAHN, NS., 2003. Comparação da dieta de duas espécies de Triportheus (Characidae, Triportheinae), em trechos do reservatório de Manso e lagoas do rio Cuiabá, Estado do Mato Grosso. Acta Scientiaru Biological Sciences, vol. 25, no. 2, p. 345-352.

GREEN, J., 1972. Frehswater ecology in the Mato Grosso, Central Brazil. II. Associations of Cladocera in meander lakes of the Rio Suiá Missú. Journal of Natural History, vol. 6, no. 2, p. 215-227.

HOLLWEDEL, W., KOTOV, AA. and BRANDORFF, GO., 2003. Cladocera (Crustacea: Branchiopoda) from the Pantanal (Brazil). Arthropoda Selecta, vol. 12 , no. 2 , p. 67-93.

LEITE, RG., 2004. The diet of matrinxá Brycon amazonicum (Pisces, Characidae) juveniles, in flooded areas of the Marchantaria Island, Amazonas, Brazil. Acta Amazonica, vol. 34, no. 4, p. 661-664.

MACHADO, FA., 2003. História natural de peixes do pantanal: com destaque em hábitos alimentares e defesa contra predadores. Campinas: Universidade Estadual de Campinas. [Tese de Doutorado].

NEVES, IF., ROCHA, O., ROCHE, KF. and PINTO, AA., 2003. Zooplankton community structure of two marginal lakes of the river Cuiabá (Mato Grosso,
Brazil) with analysis of Rotifera and Cladocera diversity. Brazilian Journal of Biology, vol. 63, no. 2, p. 329-343.

NOVAKOWSKI, GC., HAHN, NS. and FUGI, R., 2008. Diet seasonality and food overlap of the fish assemblage in a pantanal pond. Neotropical Ichthyology, vol. 6, no. 4, p. 567-576.

PIEDRAS, SRN. and POUEY, JLOF., 2005. Alimentação do peixe-rei (Odontesthes bonariensis, Atherinopsidae) nas lagoas Mirim e Mangueira, Rio Grande do Sul, Brasil. Iheringia. Série Zoologia, vol. 95, no. 2, p. 117-120.

RESENDE, EK., PEREIRA, RAC. and ALMEIDA, VLL., 1998. Peixes herbivoros da planície inundável do rio Miranda, Pantanal, Mato Grosso do Sul, Brasil. Corumbá: EMBRAPA-CPAP. 24 p. Boletim de Pesquisa, 10.

RESENDE, EK., PEREIRA, RAC., ALMEIDA, VLL. and SILVA, AG., 2000. Peixes insetivoros e zooplanctófagos da planície inundável do rio Miranda, Pantanal, Mato Grosso do Sul, Brasil. Corumbá: Embrapa Pantanal. 40 p. Boletim de Pesquisa, 17.

REY, J. and VASQUEZ, E., 1986. Contribuition a la conaissance des cladocères neotropicaux: redescription de Leydigiopsis ornata Daday 1905 (Crustacea, Cladocera). Annales de Limnologie, vol. 22, no. 2, p. 169-176.

ROBERTSON, BA., 1980. Composição, abundância e distribuição de Cladocera (Crustacea) na região de água livre da represa de Curuá-Una, PA. Manaus: Instituto Nacional de Pesquisas da Amazônia. Dissertação de Mestrado.

SHIBATTA, OA. and BENNEMANN, ST., 2003. Plasticidade alimentar em Rivulus pictus Costa (Osteichthtyes, Cyprinodontiformes, Rivulidae) de uma pequena lagoa em Brasília, Distrito Federal, Brasil. Revista Brasileira de Zoologia, vol. 20, no. 4, p. 615-618.

SHIBATTA, OA. and ROCHA, AJA., 2001. Alimentação em machos e fêmeas do pirá-brasília, Simpsonichthys boitonei Carvalho (Cyprinodontiformes, Rivulidae). Revista Brasileira de Zoologia, vol. 18, no. 2, p. 381-385.

STINGELIN, T., 1904. Entomostraken gesammelt von Dr. G. Hagmann in Mündungsgebiet des Amazones. Zoologische Jahrbucher, vol. 20, no. 6, p. 575-590.

VELA, L., 1991. Natural diet of fish from Lake Xolotlán (Managua). Aquatic Ecology, vol. 25, no. 2, p. 169-172.

WANTZEN, KM., MACHADO, FA., VOSS, M., BORISS, H. and JUNK, WJ., 2002. Seasonal isotopic shifts in fish of the Pantanal wetland, Brazil. Aquatic Sciences, vol. 64, no. 3, p. 239-251.

Received: 08 January 2010 Accepted: 15 April 2010 